\title{
Honey bee pathogens in Ghana and the presence of contaminated beeswax
}

\author{
Miguel Llorens-Picher ${ }^{1}$, Mariano Higes ${ }^{2}$, Raquel Martín-Hernández ${ }^{3}$, \\ Pilar De la Rúa ${ }^{4}$, Irene MuÑoz ${ }^{4}, \mathrm{Kwame} \mathrm{Aidoo}^{5}$, Eric Obeng BemPONG ${ }^{6}$, \\ Faustina Polkuraf ${ }^{6}$, Aránzazu Meana ${ }^{1}$
}

\footnotetext{
${ }^{1}$ Departamento de Sanidad Animal, Facultad de Veterinaria, Universidad Complutense de Madrid, 28040, Madrid, Spain ${ }^{2}$ Junta de Comunidades de Castilla-La Mancha, IRIAF, Centro de Investigación Apícola y Agroambiental (CIAPA), Laboratorio de Patología Apícola, Marchamalo, Guadalajara, Spain

${ }^{3}$ Instituto de Recursos Humanos para la Ciencia y la Tecnología (INCRECYT), Parque Científico, Albacete, Spain ${ }^{4}$ Dpto de Zoología y Antropología Física, Facultad de Veterinaria, Universidad de Murcia, 30100, Murcia, Spain ${ }^{5}$ GEF/UNEP/FAO Global Pollination Project Ghana, Department of Entomology and Wildlife, University of Cape Coast, Cape Coast, Ghana

${ }^{6}$ Animal Health and Production College, University of Cape Coast, P.O. BOX TL300, Pong-Tamale, NR, Ghana
}

Received 23 September 2016 - Revised 3 April 2017 - Accepted 11 May 2017

\begin{abstract}
A nationwide survey was performed to study the distribution of parasites, pathogens and pesticides in managed honey bee populations in Ghana. When 45 colonies were sampled and inspected for signs of disease, Varroa destructor was the most prevalent parasite $(89 \% ; n=40)$, all mites corresponding to the Korean haplotype of this pathogen. Aethina tumida $(42 \% ; n=19)$ and Braula coeca $(7 \% ; n=3)$ were also detected, as were Melissococcus plutonius and trypanosomatids (7\%). By contrast, Nosema spp., Acarapis spp., Ascosphaera apis and Paenibacillus larvae were not detected by molecular screening. Amitraz was the most widely distributed pesticide $(75 \% ; n=23)$ followed by coumaphos $(47 \% ; n=15)$, chlorpyrifos $(34 \% ; n=15)$ and fluvalinate $(31 \%$; $n=10)$. This survey lays the groundwork for further monitoring of honey bee populations in Ghana.
\end{abstract}

epidemiology / Ghana / Varroa / pesticides / honey bees

\section{INTRODUCTION}

Managed honey bees (Apis mellifera L.) are widely known for their importance as pollinators and honey producers (Allsopp et al. 2008; Strauss et al. 2013). Indeed, the productivity of many valuable crops is strongly tied to honey bee pollination services, reflecting a global value of 153 billion $€$ and a value of 11.9 billion $€$ in Africa

Electronic supplementary material The online version of this article (doi:10.1007/s13592-017-0518-2) contains supplementary material, which is available to authorized users.

Corresponding author: M. Llorens-Picher, migllore@ucm.es

Manuscript editor: Yves Le Conte alone (Gallai et al. 2009). However, these values are based on services rendered only by managed honey bees, and thus, they underestimate the true value of pollination (Allsopp et al. 2008). Wild honey bee populations are an important characteristic of sub-Saharan African countries (Moritz et al. 2005), a distinctive feature that has been neglected in smallholding crop system ecosystem services research (Garibaldi et al. 2016) where beekeeping is mostly based on trapping swarms from the wild. This contrasts considerably with Europe or North America where apiculture is breeding-based, a feature that has affected the population structure of European honey bee subspecies (De la Rúa et al. 2009).

While the health of honey bees in Europe and North America has been an important topic of 
research in recent years (Genersch 2010), the health status of honey bees in Africa has been largely ignored (Dietemann et al. 2009; Fazier et al. 2010; Strauss et al. 2013; Pirk et al. 2016). Honey bee pathogens have been detected in some studies carried out in Africa, mainly in East Africa, although unlike other parts of the world no significant deleterious effects of these pathogens were evident (Dietemann et al. 2009; Rosenkranz et al. 2010). Nevertheless, recent reports of declining feral honey bee colonies in South Africa suggest that this region may be experiencing similar colony loss to other regions around the globe (Neumann and Carreck 2010; Goulson et al. 2015).

Still, African honey bees have been considered to be more resistant or better adapted to the effects of most common parasites (Moretto et al. 1991; DeJong et al. 1997; Vieira et al. 2000; Moretto and L.J. de M. 2001). Studies into the spread and distribution of Varroa destructor (Anderson and Trueman 2000) and other pathogens in South Africa (Strauss et al. 2013, 2014a, b, 2016; Mortensen et al. 2016), Kenya (Fazier etal.2010), Uganda (Chemurot etal.2016) or Benin (Paraiso et al. 2011) support this hypothesis. However, very few surveys have been undertaken in West African countries representing a significant gap in our understanding of the incidence, prevalence, diversity and geographic distribution of honey bee diseases on that continent (Muli et al. 2014; Mumoki et al. 2014). The presence of $V$. destructor has been reported in bee colonies from Ghana (Fazier et al. 2010; Mutsaers 2012, pers. comm.), yet there is no information available as to the prevalence and haplotype of Varroa in Ghana, nor on the presence of other agents such as Nosema apis (Zander 1909), Nosema ceranae (Fries 1996) or Braula coeca (Nitzsch 1818; reviewed by Pirk et al. 2016). By contrast, some pathogens have been described in nearby countries, such as B. coeca in Benin (Paraiso et al. 2011).

In July 2013, a nationwide survey was carried out to obtain comprehensive information about the distribution of parasites, pathogens (excluding viruses) and pesticides in honey bee populations throughout Ghana. Given the relatively recent report of Varroa in this region and the lack of knowledge about the health status of honey bee colonies, this survey lays the groundwork to examine the factors affecting honey bee health in Ghana to further monitor the honey bee colony losses in this country.

\section{MATERIALS AND METHODS}

\subsection{Sample collection}

The colonies surveyed ( $n=45$ ) were distributed across 19 different geo-identified locations from the Upper East region of the country and covering seven of the ten regions in Ghana (Figure 1; Supplementary Table 1). Since there is no obligation to register as a beekeeper at any official establishment in Ghana, the list of beekeepers to be contacted was provided by Dr. Kwame Aidoo, professor at Cape Coast University (Ghana).

All samples were taken after sunset with the help of local beekeepers that manage the hives. House honey bees $(>150)$ and a piece of brood comb were taken from each hive, and where possible, both comb-stored pollen and wax were also collected and kept chilled for further analysis.

\subsection{Survey of beekeepers}

Beekeepers at each sampling location filled out a questionnaire on beekeeping skills, apiary size and management, production and health status (see Supplementary material).

\subsection{Molecular identification of honey bees and mites}

\subsubsection{DNA extraction}

Total DNA from honey bees (three worker legs) and mites (whole individuals) was extracted following a modified Chelex-based method (Walsh et al. 1991; Muñoz et al. 2008).

\subsubsection{Honey bee mtDNA analysis}

The mitochondrial haplotype of 31 worker bees from 14 different locations was determined as described previously (Evans et al. 2013) and based on sequence variation in the intergenic cox1-tRNA $^{\text {leu }}$ region (Garnery et al. 1993). 


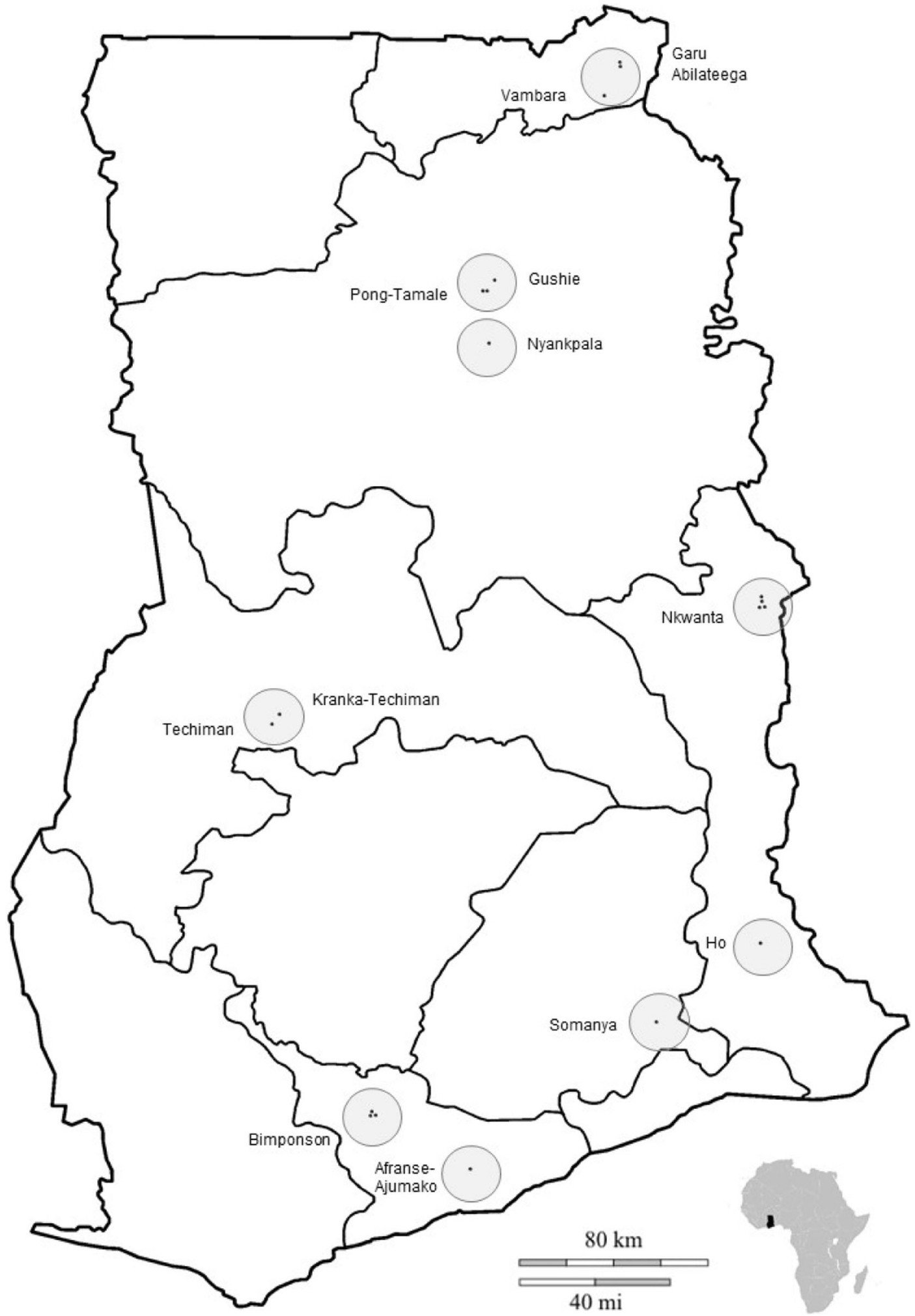

Figure 1. Map of Ghana showing the sampling sites (dots) and the names of the locations. 


\subsubsection{Mite mtDNA analysis}

A total of 19 mites from 12 different locations were identified as described previously (Anderson and Fuchs 1998; Muñoz et al. 2008) and based on PCR-RFLP of a fragment of the mitochondrial cox 1 gene following digestion with the Xho I and Sac I enzymes.

\subsection{Pathogen screening}

Varroa mite detection was performed in situ as described previously (Higes et al. 2009; Garrido Bailón 2013). Adult bees were frozen for handling, while brood cells were opened directly to count the Varroa mites. Evidence of any other pests and any other findings were also noted. Mite infestation of adult bees and brood was calculated as the number of mites per 100 bees or cells, respectively. The adult bees and brood samples were then maintained in ethanol $(70 \%)$ for PCR analyses. A broad screening of pathogens was then performed in Spain using previously published PCR assays for brood and adult pathogens (see below; Fig. 2).

\subsubsection{DNA extraction}

Samples were washed to remove the alcohol, and for each colony, 30 worker bees were macerated in $15 \mathrm{~mL} \mathrm{H}_{2} \mathrm{O}$ using sterile bags with a filter. The resulting tissue pellets were resuspended in $3 \mathrm{~mL}$ sterile water, and $400 \mu \mathrm{L}$ was transferred to a 96well plate (Qiagen) with glass beads ( $2 \mathrm{~mm}$ diameter: Sigma). Samples were then processed as described previously (Martín-Hernández et al. 2012).

\subsubsection{PCR analyses}

All PCR analyses were performed using previously published assays for brood pathogens, such as Ascosphaera apis, Paenibacillus larvae and Melissococcus plutonius (GarridoBailon et al. 2013); N. apis and N. ceranae (Martín-Hernández et al. 2012); Acarapis spp. (Garrido-Bailon et al. 2012); trypanosomatids and neogregarines (Meeus et al. 2010) and small hive beetle (SHB; Ward et al. 2007). Given that the 18S rDNA gene alone is unsuitable to define the trypanosomatid species infecting honey bee colonies, these were also studied as described elsewhere (Cepero et al.

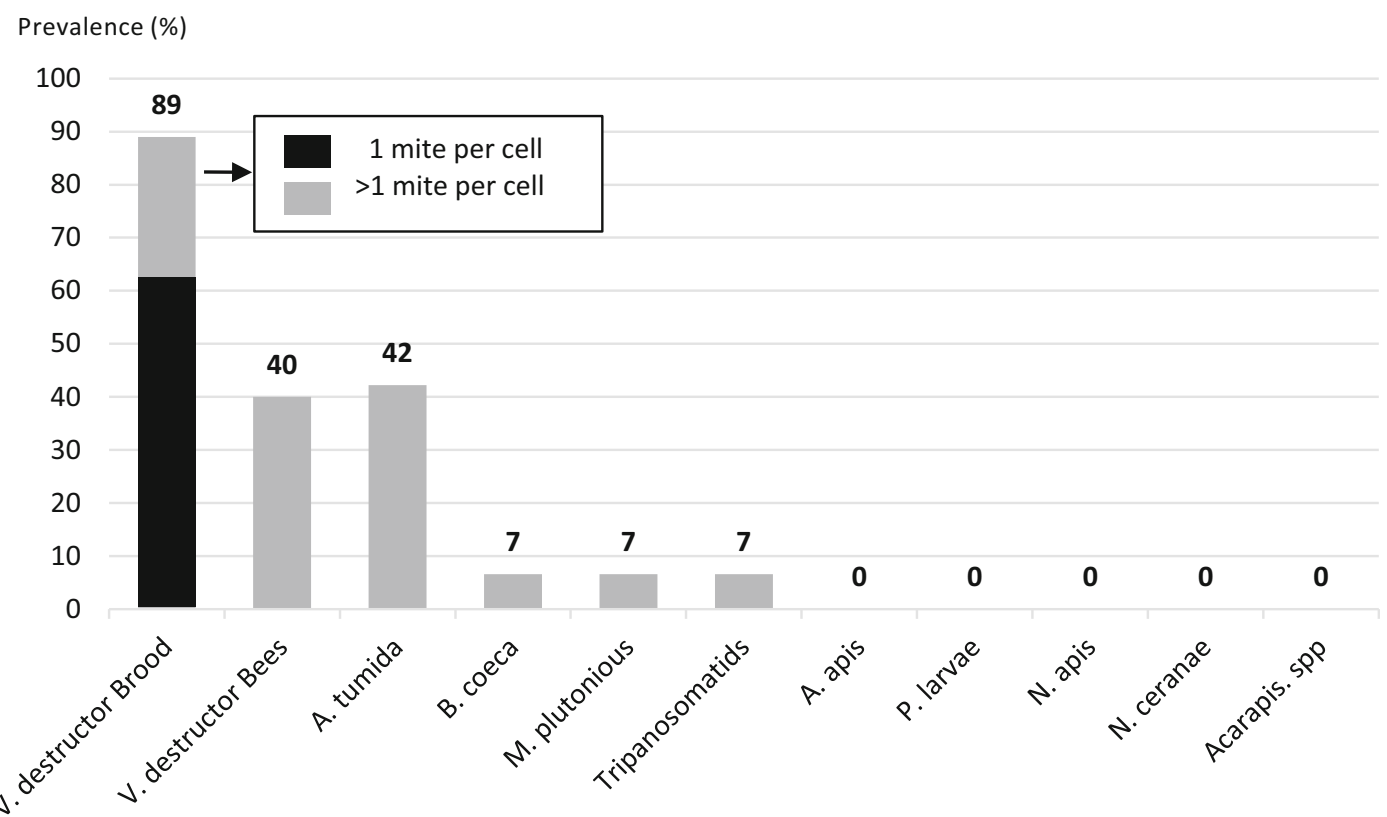

Figure 2. Pathogen prevalence in the honey bees sampled in Ghana. 
2014). All the sequences used for these analyses have been uploaded to GenBank.

\subsection{Pesticide analysis on beeswax}

Beeswax samples ( $n=32$; Table I) were analysed by Dr. Picó (Universitat de València) using a modified QuEChERS method (Krupke et al. 2012; Lambert et al. 2013) that is capable of detecting 58 compounds with a limit of detection $<10 \mathrm{ng} \mathrm{g}^{-1}$ in all cases.

\subsection{Statistical analysis}

Spearman correlation tests were performed to compare the different incidences of the pathogens and parasites detected in relation to altitude. Each sampling site was assigned an altitude value using GIS software ArcGis v.9.2 (ESRI, Redlands, CA, USA: Table I), and the statistical analysis was performed using SAS 9.4.

\section{RESULTS}

The questionnaire completed by the beekeepers showed that only 3 out of the 19 beekeepers surveyed practiced beekeeping professionally (i.e. all their income came from beekeeping), while for the majority it was a complementary work. All their managed hives were "Top Bar" hives of different shapes and none used wax foundations. While they all produced and sold honey and beeswax, only $53 \%(n=10)$ harvested propolis and $11 \%(n=2)$ pollen. Most of the beekeepers surveyed (all but two) were neither aware of the presence of $V$. destructor mites nor had they observed any negative impact on the survival and/or productivity of their honey bees. In fact, while $42 \%$ of beekeepers $(n=8)$ had lost colonies in recent years, none had attributed this to poor health but rather to the absconding phenomena. SHB and the wax moth (Galleria mellonella) were best known among the beekeepers $(74 \% ; n=14)$, yet none of the beekeepers surveyed apparently used any treatment against any pest or disease.

In terms of haplotype characterization, all the samples but one were of the African $\mathrm{A}_{\mathrm{I}}$ sublineage and three haplotypes were detected: A1 $(n=25), \mathrm{A} 4(n=3)$ and $\mathrm{A}^{\prime}(n=2)$. The other sub-lineage detected was the African sub-lineage with an Atlantic distribution $\mathrm{A}_{\text {III }}$; specifically, the A14 haplotype was detected in one colony.

Table I. Beeswax samples and pesticide analysis

\begin{tabular}{lllllll}
\hline & $\mathrm{N} \mathrm{x}$ & $N$ positives $(\%)$ & $\mu(\mathrm{ng} / \mathrm{g})$ & $\mathrm{sd}$ & Max $(\mathrm{ng} / \mathrm{g})$ & $\mathrm{Min}(\mathrm{ng} / \mathrm{g})$ \\
\hline Amitraz $^{\mathrm{a}}$ & 32 & $24(75)$ & 5556.0 & 9730.8 & 45,890 & 194 \\
Chlorfenvinphos & 32 & $1(3)$ & 20.0 & & 20 & 20 \\
Chlorpyrifos & 32 & $11(34)$ & 31.4 & 1.6 & 35 & 30 \\
$\lambda$-Cialotrin & 32 & $1(3)$ & 160.0 & & 160 & 160 \\
Coumaphos & 32 & $15(47)$ & 588.2 & 2140.4 & 8320 & 5 \\
Ethion & 32 & $1(3)$ & 40.0 & & 40 & 40 \\
Fluvalinate & 32 & $10(31)$ & 239.5 & 90.9 & 365 & 2 \\
Imazalil & 32 & $1(3)$ & 50.0 & & 50 & 50 \\
Methiocarb & 32 & $1(3)$ & 20.0 & & 20 & 20 \\
Prochloraz & 32 & $2(6)$ & 40.0 & 14.1 & 50 & 30 \\
Pyriproxyfen & 32 & $2(6)$ & 37.5 & 17.7 & 25 & 25 \\
Thiabendazole & 32 & $2(6)$ & 37.5 & 10.6 & 45 & 30 \\
Terbuthylazine-2-hydroxy & 32 & $1(3)$ & 10.0 & & 10 & 10 \\
\hline
\end{tabular}

$N$ number of analysed samples

${ }^{\text {a }}$ Amitraz was detected as its metabolite $N$-(2,4-dimethylphenyl)formamide, and values converted using their molecular mass (1 mol of N-(2,4-dimethylphenyl)formamide, whose mass is 162.0, comes from $1 \mathrm{~mol}$ of Amitraz, whose mass is 293.4) 
All the mites analysed showed 100\% similarity to the Korean $V$. destructor haplotype described previously (GenBank AF106899: Anderson and Trueman 2000). In adult bees, $V$. destructor (phoretic mites) were found in 18 colonies $(40 \%)$ with infestation levels ranging from 0.3 to $4.6 \%$ (mean $2.0 \%$, s.d. 1.3 ). Significantly higher infestation was evident in brood cells, as it was seen in 40 out of the 45 colonies sampled and with values ranging from 1.7 to $105.0 \%$ (mean $15.9 \%$, sd 22.4), representing a prevalence of $89 \%$. Occasionally, mites caused double $(n=32)$ or triple $(n=15)$ infections in cells, although the most common finding was one mite per cell $(n=352$, representing $58 \%$ of the observed prevalence). No correlation was detected between Varroa prevalence and the altitude (elevation) of the collection sites $(P=0.4)$.

Clinical inspection did not reveal any sign of varroosis, even though pests were readily detected in the colony. Indeed, $118 \mathrm{SHB}$ were collected in $42 \%(n=19)$ of the colonies when sampling adult bees, $B$. coeca was found in three colonies and wax moth ( $G$. mellonella) and big beetles (Oplostomus fuligineus) were morphologically identified $(n=2)$. Pathogen screening failed to detect any of the following agents: A. apis, P. larvae, N. apis, N. ceranae and Acarapis spp. Conversely, the bacteria $M$. plutonius was present in three samples, as were trypanosomatids, yet no clinical signs of foulbrood disease were found in the samples.

Traces of 13 pesticides were found, and none of the samples were free of such residues. The number of residues found ranged from one to nine per sample. Amitraz was the most widely distributed pesticide $(75 \%)$, and it was the pesticide detected in the highest amounts (194-45.9 ng/g), followed by coumaphos $(47 \% ; 5-8.3 \mathrm{ng} / \mathrm{g})$, chlorpyrifos $(34 \% ; 30-35 \mathrm{ng} / \mathrm{g})$ and fluvalinate $(31 \% ; 2-$ $365 \mathrm{ng} / \mathrm{g}$ ), all commonly used varrocides in $\mathrm{Eu}-$ rope and America and also used in other branches of agriculture. The remaining chemicals detected were rarely present (3-6\%), and they belonged to a wide range of agricultural or veterinary products that included thiabendazole, prochloraz or pyriproxyfen. In the questionnaire, none of the beekeepers recognized the use of any such treatments inside the hives.

\section{DISCUSSION}

There is considerable biodiversity among the A. mellifera subspecies on the African continent, yet beekeeping is not as fully developed there as it is in Europe. Indeed, 11 subspecies have been described on this continent (Ruttner 1988; Hepburn and Radloff 1998; Franck et al. 2000, 2001; Le Conte and Navajas 2008; Meixner et al. 2011): A. m. intermissa and A. m. sahariensis in northwest Africa; A. m. lamarckii in Egypt; A. $m$. simensis in Ethiopia; A. m. jemenitica, A. m. adansonii, A. m. scutellata, A. m. litorea, A. m. monticola and $A$. $m$. capensis in sub-Saharan Africa and A. m. unicolor in Madagascar, with A. $m$. adansonii being the subspecies thought to inhabit Ghana (Hepburn and Radloff 1998). In relation to the evolutionary lineages, A. m. adansonii colonies were shown to belong to two African sub-lineages, mainly $\mathrm{A}_{\mathrm{I}}$ but also $\mathrm{A}_{\mathrm{III}}$, with $\mathrm{A} 1$ and $\mathrm{A} 4$ being the most frequent haplotypes in this subspecies (Franck et al. 2001). Our results on the genetic composition of the honey bee colonies studied confirmed that it was described in other western African populations, and they corroborated the abundance of the A1 and A4 haplotypes. The presence of the A14 haplotype in these honey bees (described by De la Rúa et al. 1998 in honey bee colonies from the Canary Islands), albeit in a single unique colony, confirms the dispersion of the $\mathrm{A}_{\text {III }}$ sub-lineage along the Atlantic coast of Africa.

The honey bee mite $V$. destructor represents the greatest threat to apiculture, and it is found almost universally (Rosenkranz et al. 2010). The presence of $V$. destructor was first described in one region in Ghana (Fazier et al. 2010), while the present data shows it to be widely distributed in all the regions sampled, although the Korean haplotype was the only one found. This haplotype is considered to be more virulent than the Japanese haplotype (Anderson and Trueman 2000), and it has also been reported in other African countries (Allsopp et al. 1997; Dietemann et al. 2009; Fazier et al. 2010; Muli et al. 2014; Mumoki et al. 2014; Chemurot et al. 2016), supporting the hypothesis that this mite is spreading throughout the continent.

A relatively high mean Varroa prevalence was found in brood, higher than that reported 
previously in Ghana (Fazier et al. 2010) and more similar to that reported for East Africa (Muli et al. 2014). Indeed, infestation rates are above the treatment threshold recognized for managed colonies in European subspecies of A. mellifera (Delaplane and Hood 1997). This high rate raises the question if indeed all colonies are tolerant, or if at current they are experiencing a selection process. Without underestimating the natural selection processes, it is important to note that no clinical signs of varroosis were detected on inspection (depopulation, deformed wings or brood abnormalities), supporting previous suggestions that African honeybees are more tolerant to Varroa mite infestation (Martin and Medina 2004; Dietemann et al. 2009; Muli et al. 2014; Strauss et al. 2014a). This tolerance might be related to the cell size, and the shorter capped time of both worker and drone cells (Martin and Medina 2004; Rosenkranz et al. 2010). These observations might also reflect the lower preference of the mites for worker cells in this honey bee species, explaining the fewer double or triple infestations found. This would also explain the low numbers of mites found on adult bees, and the relatively low levels observed in their brood in terms of prevalence and infection rates, similar to those reported in other east African countries (Muli et al. 2014; Chemurot et al. 2016; Mortensen et al. 2016).

Another consideration on the high infestation rates would be whether this represents an invasion wave or not. Allsopp (2006) observed very high mite levels before the development of mite tolerance, which took 3 to 5 years in the Cape honeybee (Apis mellifera capensis) and six to seven in the Savanna honeybee (Apis mellifera scutellata). According to Mutsaers (2012, pers. comm.), Varroa mites are present in Northern Ghana at least since early 2008, being more likely that infestation levels found are due to the local subspecies tolerance to the mite and not to an invasion wave.

Ghana is located in a tropical region between the Equator and the Tropic of Cancer, with big differences in climate across the country. The North has a typically longer dry season than the South, with rainfall over a shorter period. Latitude has been suggested to be linked to Varroa levels in some areas due to the distinct environmental conditions, although infestation rates may vary for a number of reasons (Rosenkranz et al. 2010). Thus, a correlation with latitude might be due to some specific coincidences. In this study, no correlation was found between the Varroa levels in hives and the altitude of the sampling site, in accordance with other data from tropical climates (Chemurot et al. 2016; Mortensen et al. 2016).

Small hive beetle (Aethina tumida) is known to represent no threat in sub-Saharan Africa since it is endemic to this region (Dietemann et al. 2009) and honey bees have co-evolved with it. However, high infestation rates might be responsible for some deleterious effects both at the colony level and in terms of production. SHB was distributed extensively in the samples studied here, yet no clinical effects were attributed to its presence.

The identification of $B$. coeca represents the first time this parasite has been found in Ghanaian honey bee colonies. Given the high prevalence of pesticides found in wax, it is a surprising finding, as most of the compounds found are thought to act as both insecticides and acaricides. However, the Braula levels detected are very low, similar to those reported in the bordering Benin (Paraiso et al. 2011), and so it can be considered a sporadic finding. In Europe, the widespread use of pesticides to control Varroa has eliminated Braula from most European honeybee colonies, and a similar situation in Ghana (with high levels of pesticides in the hives) might explain this result.

The low levels of $O$. fuligineus found indicate that this pest currently does not suppose a serious health problem; even high levels can be problematic (Hepburn and Radloff 1998, reviewed by Pirk et al. 2016).

Molecular tools are very effective when identifying pathogens, although their detection should always be correlated to clinical signs in the host for a disease to be diagnosed. Detection of M. plutonius in Ghana is not new (reviewed by Pirk et al. 2016), yet its low levels of detection and the absence of signs of foulbrood disease are a good indicator of health. This is the first time trypanosomatids have been detected in an African country. While their true effect on honey bee health is still unknown, their 
presence has recently been correlated with colony losses in the USA and Belgium, especially when detected in conjunction with $N$. ceranae (Cornman et al. 2012; Runckel et al. 2011; Ravoet et al. 2013), although $N$. ceranae was not detected here in any sample.

To date, there has been no evidence of pesticides in beeswax from Ghana and according to the beekeeper's survey, no treatment was applied to the colonies and beeswax is not reused in foundations. Acaricides, herbicides and other insecticides are the most prevalent chemical residues found in managed colonies in Europe and North America (Bernal et al. 2010; Johnson et al. 2010; Mullin et al. 2010; Lambert et al. 2013), which were also the most prevalent chemical families found in this study. All pesticide levels were low compared to those reported from studies in Europe (Vázquez et al. 2015; García et al. 2017), with the exception of two of them: Amitraz and coumaphos.

These results are worrisome due to the high prevalence found and because the route of exposure remains unclear. One hypothesis might be that beekeepers are pouring different commonly used pesticides for agriculture or tick control, in the areas surrounding the hives to avoid problems with ants or other common pests. Honey bee colonies seem to act as a sink for pesticides in the environment. While honey bees are sensible to toxic substances, their entry into the hive depends on particular circumstances of the colony and its individuals (Johnson 2015). Beeswax trade has in the past gone from Africa to Europe; therefore, it seems unlikely that Ghana had imported polluted wax, raising the need to clarify both the route of exposure and the health impact of these high levels of the different compounds.

This survey provides key data for both researchers and beekeepers in Ghana. The results show that Varroa has spread to Ghana and is well established, while beekeepers are unaware of this, suggesting that it is indeed not a problem for their bees. However, the beeswax contains several well-known varroacides, and how these may have come into the hives remains unknown.
This work lays the groundwork for further monitoring of bee populations in West Africa. The data presented here are an initial incursion into the examination of the factors affecting honey bee health in a West African country. It was noteworthy that few pathogens were detected, including some of those directly linked to the colony collapse phenomena in Europe and North America. Monitoring this health situation may help clarify if honey bee colony losses are also occurring in this geographical area and, if so, what is the cause.

\section{ACKNOWLEDGEMENTS}

The authors wish to acknowledge the help and support received by beekeepers from all over Ghana, with special mention to the staff at the Animal Health and Production College at Pong-Tamale, Dr. Rosa Gálvez for her support using GIS software and Airbus Defence and Space for their funding. IM was supported by a postdoctoral fellowship from the University of Murcia (R-1017/2015). PDLR received support from the COST Action FA1307 (SUPER-B). Financial support for this research was also provided by the 19908-GERM-15 project of Regional Excellence from the Fundación Séneca (Gobierno Regional de Murcia, Spain).

\section{AUTHORS' CONTRIBUTIONS}

MLl-P wrote the paper and together with AM conceived and performed this research; KA, EOB and FP gave local support; $\mathrm{MH}$ and $\mathrm{RM}-\mathrm{H}$ helped with analyses and PR and IM did the haplotype identification.

Pathogènes de l'abeille au Ghana et présence de cire contaminée

Epidémiologie / Afrique de l'Ouest / varroa / pesticides / Apis mellifera

Pathogene der Honigbienen in Ghana und das Vorhandensein von kontaminiertem Bienenwachs

Epidemiologie / Ghana / Varroa / Pestizide / Apis mellifera 


\section{REFERENCES}

Allsopp, M. (2006) Analysis of Varroa destructor infestation of southern African honeybee populations. Master Thesis, University of Pretoria. Pretoria

Allsopp, M., Govan, V., Davison, S. (1997) Bee health report: Varroa in South Africa. Bee World 78, 171174

Allsopp, M.H., de Lange, W.J., Veldtman, R. (2008) Valuing Insect Pollination Services with Cost of Replacement. PLoS One 3, e03128

Anderson, D.L., Fuchs, S. (1998) Two genetically distinct populations of Varroa jacobsoni with contrasting reproductive abilities on Apis mellifera. J. Apic. Res. 37, 69-78

Anderson, D.L., Trueman, J.W. (2000) Varroa jacobsoni (Acari: Varroidae) is more than one species. Exp. Appl. Acarol. 24, 165-189

Bernal, J., Garrido-Bailón, E., Del Nozal, M.J., GonzálezPorto, A.V., Martín-Hernández, R., Diego, J.C., Jiménez, J.J., Bernal, J.L., Higes, M. (2010) Overview of Pesticide Residues in Stored Pollen and Their Potential Effect on Bee Colony (Apis mellifera) Losses in Spain. J. Econ. Entomol. 103, 1964-1971

Cepero, A., Ravoet, J., Gómez-Moracho, T., Bernal, J.L., Del Nozal, M.J., Bartolomé, C., Maside, X., Meana, A., González-Porto, A.V., de Graaf, D.C., MartínHernández, R., Higes, M. (2014) Holistic screening of collapsing honey bee colonies in Spain: a case study. BMC. Res. Notes. 7, 649

Chemurot, M., Akol, A.M., Masembe, C., de Smet, L., Descamps, T., de Graaf, D.C. (2016) Factors influencing the prevalence and infestation levels of Varroa destructor in honeybee colonies in two highland agro-ecological zones of Uganda. Exp. Appl. Acarol. 68, 497-508

Cornman, R.S., Tarpy, D.R., Chen, Y., Jeffreys, L., Lopez, D., Pettis, J.S., vanEngelsdorp, D., Evans, J.D. (2012) Pathogen webs in collapsing honey bee colonies. PLoS ONE 7, e043562

De la Rúa, P., Serrano, J., Galián, J. (1998). Mitochondrial DNA variability in the Canary Islands honeybees (Apis mellifera L.). Mol. Ecol. 7 (11), 1543-1547

De la Rúa, P., Jaffe, R., Dall'Olio, R., Muñoz, I., Serrano, J. (2009) Biodiversity, conservation and current threats to European honeybees. Apidologie 40, 263-284

DeJong, D., Faculdade de M., Soares, A.E.E. (1997) An isolated population of Italian bees that has survived Varroa jacobsoni infestation without treatment for over 12 years. Am. Bee J. 137 (10), 742-745

Delaplane, K.S., Hood, W.M. (1997) Effects of delayed acaricide treatment in honey bee colonies parasitized by Varroa jacobsoni and a lateseason treatment threshold for the southeastern USA. J. Apic. Res. 36, 125-132

Dietemann, V., Pirk, C.W.W., Crewe, R. (2009) Is there a need for conservation of honeybees in Africa? Apidologie 40, 285-295
Evans, J.D., Schwarz, R.S., Chen, Y.P., Budge, G., Cornman, R.S., et al. (2013) Standard methods for molecular research in Apis mellifera. J. Apic. Res. 52 (4), UNSP 52.4.11

Fazier, M., Muli, E., Conklin, T., Schmehl, D., Torto, B., Frazier, J., Tumlinson, J., Evans, J.D., Raina, S. (2010) A scientific note on Varroa destructor found in East Africa; threat or opportunity? Apidologie 41, 463-465

Franck, P., Garnery, L., Solignac, M., Cornuet, J.M. (2000) Molecular confirmation of a fourth lineage in honeybees from the Near East. Apidologie 31, 167-180

Franck, P., Garnery, L., Loiseau, A., Oldroyd, B.P., Hepburn, H.R., Solignac, M. Cornuet, J.M. (2001) Genetic diversity of the honeybee in Africa: microsatellite and mitochondrial data. Heredity 86, 420430

Gallai, N., Salles, J.-M., Settele, J., Vaissière, B.E. (2009) Economic valuation of the vulnerability of world agriculture confronted with pollinator decline. Ecol. Econ. 68, 810-821

García, M.D.G., Uclés, S., Fernández, A.B.L., Sosa, A., Fernández-Alba, A.R. (2017) Multiresidue method for trace pesticide analysis in honeybee wax comb by GCQqQ-MS. Talanta 163, 54-64

Garibaldi, L.A., Carvalheiro, L.G., Vaissière, B.E., Gemmill-Herren, B., Hipólito, J., et al. (2016) Mutually beneficial pollinator diversity and crop yield outcomes in small and large farms. Science 351, 388-391

Garnery, L., Solignac, M., Celebrano, G., Cornuet, J.M. (1993) A simple test using restricted PCR-amplified mitochondrial DNA to study the genetic structure of Apis mellifera L. Experientia 49, 1016-1021

Garrido Bailón, M.E. (2013) Repercusión potencial en la cabaña apícola española de agentes nosógenos detectados en colonias de Apis mellifera iberiensis (info:eu-repo/semantics/doctoralThesis). Universidad Complutense de Madrid, Madrid

Garrido-Bailon, E., Bartolome, C., Prieto, L., Botias, C., Martinez-Salvador, A., Meana, A., Martin-Hernandez, R., Higes, M. (2012) The prevalence of Acarapis woodi in Spanish honey bee (Apis mellifera) colonies. Exp. Parasitol. 132 , 530-536

Garrido-Bailon, E., Higes, M., Martinez-Salvador, A., Antunez, K., Botias, C., Meana, A., Prieto, L., Martin-Hernandez, R. (2013) The prevalence of the honeybee brood pathogens Ascosphaera apis, Paenibacillus larvae and Melissococcus plutonius in Spanish apiaries determined with a new multiplex PCR assay. Microb. Biotechnol. 6, 731-739

Genersch, E. (2010) Honey bee pathology: current threats to honey bees and beekeeping. Appl. Microbiol. Biotechnol. 87, 87-97

Goulson, D., Nicholls, E., Botias, C., Rotheray, E.L. (2015) Bee declines driven by combined stress from parasites, pesticides, and lack of flowers. Science 347, e1255957

Hepburn, H. R., Radloff, S.E. (1998) Honeybees of Africa. Springer, Berlin. 
Higes, M., Martín-Hernández, R., Garrido-Bailón, E., González-Porto, A.V., García-Palencia, P., Meana, A., Del Nozal, M.J., Mayo, R., Bernal, J.L. (2009) Honeybee colony collapse due to Nosema ceranae in professional apiaries. Environ. Microbiol. Rep. 1, 110-113

Johnson, R.M. (2015) Honey Bee Toxicology. Annu. Rev. Entomol. 60, 415-434

Johnson, R.M., Ellis, M.D., Mullin, C.A., Frazier, M. (2010) Pesticides and honey bee toxicity - USA. Apidologie 41, 312-331

Krupke, C.H., Hunt, G.J., Eitzer, B.D., Andino, G., Given, K. (2012) Multiple Routes of Pesticide Exposure for Honey Bees Living Near Agricultural Fields. PLoS One 7, e29268

Lambert, O., Piroux, M., Puyo, S., Thorin, C., L'Hostis, M., Wiest, L., Buleté, A., Delbac, F., Pouliquen, H. (2013) Widespread Occurrence of Chemical Residues in Beehive Matrices from Apiaries Located in Different Landscapes of Western France. PLoS One 8, e67007

Le Conte, Y., Navajas, M. (2008) Climate change: Impact on honey bee populations and diseases. OIE Rev. Sci. Tech. 27 (2), 485-510

Martin, S.J., Medina, L.M. (2004) Africanized honeybees have unique tolerance to Varroa mites. Trends Parasitol. 20, 112-114

Martín-Hernández, R., Botías, C., Bailón, E.G., MartínezSalvador, A., Prieto, L., Meana, A., Higes, M. (2012) Microsporidia infecting Apis mellifera: Coexistence or competition. Is Nosema ceranae replacing Nosema apis? Environ. Microbiol. 14, 2127-2138

Meeus, I., De, G., Jans, K., Smagghe, G. (2010) Multiplex PCR detection of slowly-evolving trypanosomatids and neogregarines in bumblebees using broad-range primers. J. Appl. Microbiol. 109, 107-115

Meixner, M.D., Leta, M.A., Koeniger, N., Fuchs, S. (2011) The honey bees of Ethiopia represent a new subspecies of Apis mellifera -Apis mellifera simensis n. ssp. Apidologie 42, 425-437

Moretto, G., Jr, L.J. de M. (2001) Infestation and distribution of the mite Varroa jacobsoni in africanized honey bee (Apis mellifera) colonies. Interciencia 26, 394-396

Moretto, G., Gonçalves, L.S., De Jong, D., Bichuette, M.Z. (1991) The effects of climate and bee race on Varroa jacobsoni Oud infestations in Brazil. Apidologie 22, 197-203

Moritz, R.F.A., Härtel, S., Neumann, P. (2005) Global invasions of the western honeybee (Apis mellifera) and the consequences for biodiversity. Ecoscience 12, 289-301

Mortensen, A.N., Schmehl, D.R., Allsopp, M., Bustamante, T.A., Kimmel, C.B., Dykes, M.E., Ellis, J.D. (2016) Differences in Varroa destructor infestation rates of two indigenous subspecies of Apis mellifera in the Republic of South Africa. Exp. Appl. Acarol. 68, 509-15

Muli, E., Patch, H., Frazier, M., Frazier, J., Torto, B., et al. (2014) Evaluation of the Distribution and Impacts of
Parasites, Pathogens, and Pesticides on Honey Bee (Apis mellifera) Populations in East Africa. PLoS One 9, e094459

Mullin, C.A., Frazier, M., Frazier, J.L., Ashcraft, S., Simonds, R., vanEngelsdorp, D., Pettis, J.S. (2010) High Levels of Miticides and Agrochemicals in North American Apiaries: Implications for Honey Bee Health. PLoS One 5, e09754

Mumoki, F.N., Fombong, A., Muli, E., Muigai, W.T., Masiga, D. (2014) An inventory of documented diseases of African honeybees. Afr. Entomol. 22 , 473-487

Muñoz, I., Garrido-Bailón, E., Martín-Hernández, R., Meana, A., Higes, M., Rúa, P.D. la (2008) Genetic profile of Varroa destructor infesting Apis mellifera iberiensis colonies. J. Apic. Res. 47, 310-313

Neumann, P., Carreck, N.L. (2010) Honey bee colony losses. J. Apic. Res. 49, 1-6

Paraiso, A., Cornelissen, B., Viniwanou, N. (2011) Varroa destructor infestation of honey bee (Apis mellifera adansonii ) colonies in Benin. J. Apic. Res. 50, 321-322

Pirk, C.W.W., Strauss, U., Yusuf, A.A., Demares, F., Human, H. (2016) Honeybee health in Africa-a review. Apidologie 47, 276-300

Ravoet, J., Maharramov, J., Meeus, I., De Smet, L., Wenseleers, T., Smagghe, G., de Graaf, D.C. (2013) Comprehensive Bee Pathogen Screening in Belgium Reveals Crithidia mellificae as a New Contributory Factor to Winter Mortality. PLoS One 8, e 72443

Rosenkranz, P., Aumeier, P., Ziegelmann, B. (2010) Biology and control of Varroa destructor. J. Invertebr. Pathol. 103 Suppl 1, S96-119

Runckel, C., Flenniken, M.L., Engel, J.C., Ruby, J.G., Ganem, D., Andino, R., DeRisi, J.L. (2011) Temporal analysis of the honey bee microbiome reveals four novel viruses and seasonal prevalence of known viruses, Nosema, and Crithidia . PLoS One 6, e20656

Ruttner, F. (1988) Biogeography and Taxonomy of Honeybees. Springer-Verlag, Berlin.

Strauss, U., Human, H., Gauthier, L., Crewe, R.M., Dietemann, V., Pirk, C.W.W. (2013) Seasonal prevalence of pathogens and parasites in the savannah honeybee (Apis mellifera scutellata). J. Invertebr. Pathol. $114,45-52$

Strauss, U., Pirk, C.W.W., Crewe, R.M., Human, H., Dietemann, V. (2014a) Impact of Varroa destructor on honeybee (Apis mellifera scutellata) colony development in South Africa. Exp. Appl. Acarol. 65, 89106

Strauss, U., Pirk, C.W.W., Dietemann, V., Crewe, R.M., Human, H. (2014b) Infestation rates of Varroa destructor and Braula coeca in the savannah honey bee (Apis mellifera scutellata ). J. Apic. Res. 53, 475477

Strauss, U., Dietemann, V., Human, H., Crewe, R.M., Pirk, C.W.W. (2016) Resistance rather than tolerance explains survival of savannah honeybees (Apis mellifera 
scutellata) to infestation by the parasitic mite Varroa destructor. Parasitology 143, 374-387

Vázquez, P. P., Lozano, A., Uclés, S., Ramos, M. M. G., Fernández-Alba, A. R. (2015) A sensitive and efficient method for routine pesticide multiresidue analysis in bee pollen samples using gas and liquid chromatography coupled to tandem mass spectrometry. J Chromatogr. A. 1426, 161-173.

Vieira, J.C., Gonçalves, L.S., Jong, D.D. (2000) Africanized honey bees (Apis mellifera L.) are more efficient at removing worker brood artificially infested with the parasitic mite Varroa jacobsoni Oudemans than are Italian bees or Italian/Africanized hybrids. Genet. Mol. Biol. 23, 89-92

Walsh, P.S., Metzger, D.A., Higuchi, R. (1991) Chelex 100 as a medium for simple extraction of DNA for PCRbased typing from forensic material. BioTechniques 10, 506-513

Ward, L., Brown, M., Neumann, P., Wilkins, S., Pettis, J., Boonham, N. (2007) A DNA method for screening hive debris for the presence of small hive beetle (Aethina tumida). Apidologie 38, 272-280 